\title{
The application of manufacturing audits to identify and analyze production strategies: study carried out in a small graphics company
}

Shirley Suellen Thesari ${ }^{1}$, Federal Technological University of Paraná, Paraná, Brazil

Renato Tonello ${ }^{2}$, Federal Technological University of Paraná, Paraná, Brazil

Flavio Trojan ${ }^{3}$, Federal Technological University of Paraná, Paraná, Brazil

Mauro Lizot ${ }^{4}$, Federal Technological University of Paraná, Paraná, Brazil

\section{RESUMO}

Objetivo - Este trabalho pretende identificar, analisar e formular estratégias de manufatura para pequenas empresas. As aplicações das metodologias de gestão nos processos de manufatura das empresas de pequeno porte não são comumente adotadas, pois se entende que não gerariam nenhum retorno imediato, se comparado ao esforço necessário para entender e executar tais aplicações.

Desenho / metodologia / abordagem - É utilizada uma adaptação da metodologia de auditoria de manufatura, ilustrado por uma aplicação em uma indústria gráfica de pequeno porte.

Resultados - A situação que se verifica com maior frequência em empresas de administração familiar, de pequeno porte, onde nem mesmo a profissionalização das atividades é considerada relevante, sendo encarada como um desperdício de esforços e recursos, pode certamente ser melhorada com a auditoria de manufatura. Porém, com o avanço tecnológico, mesmo as pequenas empresas precisam evoluir e refletir sobre estratégias de manufatura, a fim de permanecer no mercado.

Originalidade / valor - Essa abordagem torna-se eficiente quando direciona e analisa essas estratégias, que comumente não são claras para empresas deste porte o que proporciona identificar pontos fracos e oportunidades de melhoria para alavancar a competividade dessas empresas, pela definição de estratégias mais eficazes. Além disso, o trabalho contribui teoricamente quando procura ajustar uma metodologia já consolidada em grandes corporações, e que precisou ser adaptada à realidade do cenário apresentado.

Palavras-chave - Estratégia de manufatura, auditorias, indústria gráfica.

\section{ABSTRACT}

Purpose - This study intends to identify, analyze and formulate manufacturing strategies for small companies. The application of management methodologies on manufacturing processes in small companies is not commonly adopted, since an immediate return is not generated, and when it is compared to the effort required to understand and apply it.

Design/methodology/approach - An adaption to a manufacturing audit methodology was used, illustrated by using the application to a small printing company.

Findings - The situation that occurs frequently in small and family-owned enterprises, where even making activities more professional is not considered relevant, and seen as a waste of time and money, can certainly be improved using manufacturing audits. However, with technological advances, even small companies need to develop and reflect on manufacturing strategies to remain in the market.

Originality/value - This approach becomes efficient when it focuses and analyzes these strategies, which are usually unclear for small companies, identifying weaknesses and opportunities for improvement to leverage the competitiveness of these companies, by defining more effective strategies. In addition, the study contributes theoretically when it seeks to adjust a methodology that has already been consolidated in large corporations, and which needs to be adapted to the reality of the scenario presented.

Keywords - Manufacturing strategy, auditing, printing industry.

1. Av. Sete de Setembro, 3165 - Rebouças CEP 80230-901 - Curitiba - PR - Brasil, shirleythesari@gmail.com, https://orcid.org/0000-0003-4216-3935; renatotonello@yahoo.com.br, https://orcid.org/0000-0003-1111-0072; 3. trojan@utfpr.edu.br, https://orcid.org/0000-0003-2274-5321; 4. mauro.lizot@unochapeco.edu.br, https://orcid.org/00000003-2325-070X.

THESARI, S.S.; TONELLO, R.; TROJAN, F.; LIZOT, M. The application of manufacturing audits to identify and analyze production strategies: study carried out in a small graphics company. GEPROS. Gestão da Produção, Operações e Sistemas, v.16, $\mathrm{n}^{\circ}$ 3, p. 21 - 42, 2021.

DOI: http://dx.doi.org/10.15675/gepros.v16i3.2501 


\section{INTRODUCTION}

The formulation of manufacturing strategies has an extremely positive effect on manufacturing performance, especially in areas such as supply, cost and quality. (NURCAHYO; WIBOWO, 2015). This has been considered a key task for production management, but it is often not easy understood or a simple task (PLATTS et al., 1996).

Existing studies on the subject commonly develop methodologies for the gaps present in large companies. However, especially in the printing industry, which is the applied part of this work, these methodologies are not totally suitable for Micro and Small Companies, due to the particularities of this type of company.

Since these companies are clearly important also in the Brazilian economic scenario, which can be observed through the formation of a national business community, diversification of the export agenda and the capacity to generate employment and income (SEBRAE, 2014). It justifies the importance of studying of strategies and adaptation of methodologies for this industrial sector (FILHO; NUNES, 2010; SHAH; SHRIVASTAVA, 2013).

According to surveys conducted in 2015 by ABIGRAF (2015), in a sample of 20,000 companies, revealed that the occupation of the printing industries added up to a production equivalent to $\mathrm{R} \$ 45$ billion in this sample. The printing industries also presented in that year a ratio of $0.3 \%$ of the Brazilian GDP, and $2.8 \%$ of the industrial Brazilian GDP.

Also, according to data released by the Department of Economic Studies ABIGRAF (2019), there were 19,142 printing companies in Brazil employing 181,193 workers, and 97\% of these companies were small.

In the literature related to the formulation of manufacturing strategies, pointed out competitive priorities as strategic resources capable of helping organizations to create, develop and maintain a competitive advantage (GOBBO et al., 2010; AWWAD et al., 2013). Most of the papers were basically focused on descriptive processes and conceptual models, without the ability to assess the degree of support of the manufacturing strategy for competitive priorities in organizations. (JIA; BAI, 2011).

By formulating a manufacturing strategy in small companies, it is possible to improve manufacturing potential, which leads to increase competitiveness for these companies. However, despite being seen as an important approach, many gaps still exist in the empirical 
work related to the use of manufacturing strategies for small and medium companies, mainly in an international context (THUN, 2008; SATTAR; JAVEED; LATIEF, 2020).

In addition to conduct a more efficient industrial plant manufacturing management strategies is necessaty to allow other aspects related to good management practices in an integrated manner (PIRAN et al., 2016), such as correct risk management and efficient sales price formation, increased market response, improved financial results (LIZOT et al., 2020). By the digital communication evolution, the printing industry has needed to reinvent its processes with more efficient production forms that could be done through management strategies for manufacturing (ABIGRAF, 2018).

The manufacturing audit process is important to ensure that production lines are operating in compliance with quality and safety, in order to manage and detect potential issues in the early stages of the process (GRANILLO-MACÍAS et al., 2020).

The sector that represents the printing industries, which was explored in this article, is divided into the segments of: inputs, editorial process and graphic process (KAI et al., 2014). Similarly, the company studied in this work has its processes divided among prepress services process, product printing and finishing services. This sector is characterized as a service activity, due to its production and demand particularities, and the fact that there is a change in raw material, including graphic services into the manufacturing industry (FIEP, 2018). The national graphic industrial branch comprises approximately $88 \%$ of small businesses (ABIG, 2009).

Thus, the objective of this work is to present an adaptation for small organizations of the Manufacturing Audit method, proposed by (PLATTS; GREGORY, 1990). This adaptation was also applied in an exploratory study of a small printing industry in the south of Brazil. It is noticed that this scarcity of studies on manufacturing auditing in small and medium companies generates the opportunity to explore adaptations in methodologies already consolidated on large corporations and encourage new, even more in-depth studies to identify the importance of formulating manufacturing strategies, regardless of size, since small companies combined have relevant representation in the country's economy.

The article was structured as follows: this section contextualizes the theme, presents the gap and the general objective, as well as its justificatives, then the theoretical framework on the themes: Strategy in Manufacturing and Auditing in Manufacturing is presented. Subsequently, the procedures for data collection and analysis were described. Finally, the 
results and contributions of the study punctuated in the conclusions and, at the end, the references used to compose this study are presented.

\section{THEORETICAL FOUNDATION}

\subsection{Manufacturing Strategy}

The strategy formulated for a company must specify the type of competitive advantage it seeks in its market in order to articulate the way in which this advantage should be achieved (HAYES; PISANO, 1994; GOBBO, et al., 2010). The importance of adopting clear strategies in organizations meets the company's objectives, when seeking ways to leverage the product in the market (SINGH; MAHMOOD, 2014). Strategy can be defined as the creation of a unique position, i.e., there is no ideal position that all companies can achieve to win over customers (PORTER, 1996). However, managing strategically requires multidisciplinary knowledge, flexibility and easy perception of all trends of the environment conditions where it operates, and situations that are often unpredictable or difficult to interpret (WEBER; POLO, 2007; SATTAR; JAVEED; LATIEF, 2020).

Thus, the essence of strategic positioning may be to choose paths and activities different from those presented by competitors (SINGH; MAHMOOD, 2014). In this way, there will always be trade-offs when defining a strategic position. Companies should not try to be all things to all customers. Positions and trade-offs are essential to the strategy, as they create the need for choice and limit what the company offers (NAIR, et al., 2021). The organization positioning is closely related to its focus. The factory that focuses on a mix of products will surpass the conventional plant, which tries to grasp a broader mission (SKINNER, 1974). There are three basic concepts about focused manufacturing: many other ways to increase and eliminate besides producing at low cost; a factory will not perform well on all criteria at the same time and the simplicity and repetition increase competence. Manufacturing industries need to improve their process flows, allocating resources for this task and also to improve productivity (DHIRAVIDAMANI et al., 2017).

According to Mintzenberg (1987), the strategy can still be defined through Plan, Pretext, Pattern, Position and Perspective. This definition was inserted before the period of technological expansion of manufacturing and can help the managers with the perception of the variety of functions in which the strategy can act: 
- Plan: in which the strategy becomes a consciously intended objective. It has two essential characteristics: it is elaborated in advance of the actions to which it is applied and developed consciously and purposefully.

- Pretext: it represents a conscious "maneuver" to overcome competitors.

- Pattern: while plans may not be carried out, patterns may appear without preconception.

- Position: can be pre-selected and desired through a plan and/or it can be achieved, maybe even found, through a pattern of behavior.

- Perspective: the strategy can be a shared perspective, through its intentions or through its actions.

Research in manufacturing strategy is sparse, being mostly concentrated within the vision of strategy (PLATTS; GREGORY, 1990). Skinner was the first to mention the concept of strategy in the manufacturing area in 1969, according to Golec, (2015), who introduced this study by exploring the properties of the manufacturing function that could help achieve competitive advantages. For Arafa and Elmaraghy, (2011) manufacturing strategy is a standardized set of structural and infrastructure decisions that determine the system's capacity to comply with production objectives that are compatible with business objectives.

The manufacturing strategy helps to improve fundamental production capabilities, support and guide corporate business, production and is also a determining factor in gaining competitive advantages (BOUCHER et al., 2007; DHIRAVIDAMANI et al., 2018).

Operational efficiency can be measured as the way to perform similar activities better than their market competitors (PATAH; CARVALHO, 2009). Hayes e Wheelwright (1985) addressed the competitiveness built through manufacturing, with an approach in a period of economic instability. According to them, manufacturing must play several roles in the organization, which can be seen as the development phases along a continuum. Therefore, managers must understand this sequence in order to identify the real situation and the attitude that must be taken to advance in the internship. The stages of competitive effectiveness through manufacturing are discussed below (HAYES; WHEELWRIGHT, 1985; NAIR et al., 2021):

- Stage 01: Managers consider the role of manufacturing as neutral (unable to influence competitive success). Thus, the concern revolves around eliminating the negative impacts that may be generated. 
- Stage 02: At this stage, companies seek external neutrality in relation to competitors. In other words, unlike the previous stage, there is a concern to achieve parity with the main competitors.

- Stage 03: Organizations look at manufacturing as an "internal support" where their contribution is derived and dictated by the overall business strategy. In other words, the expectation that falls on manufacturing is greater than in relation to the previous stages.

- Stage 04: The role of manufacturing in this stage is to support "externally", where the company's competitive strategy is structured on its production capacity.

Voss (1995) analyzed the paradigms that emerged over time on manufacturing strategies and they are presents until now. Table 01 lists the key points of each one.

Table 01- Key concepts of manufacturing strategy paradigms

\begin{tabular}{l|c|c|c} 
& $\begin{array}{c}\text { Competing through } \\
\text { Manufacturing }\end{array}$ & $\begin{array}{c}\text { Strategic Choices in } \\
\text { Manufacturing }\end{array}$ & Best practice \\
\hline \multirow{5}{*}{ Key Concepts } & Order winners & $\begin{array}{c}\text { Contingency } \\
\text { approaches }\end{array}$ & World class manufacturing \\
\cline { 2 - 4 } & Key succes factors & $\begin{array}{c}\text { Internal and external } \\
\text { consistency }\end{array}$ & Benchmarking \\
\cline { 2 - 4 } & Capacity & Choice of process & Process reengineering \\
\cline { 2 - 4 } & $\begin{array}{c}\text { Generic Manufacturing } \\
\text { Strategies }\end{array}$ & $\begin{array}{c}\text { Process and } \\
\text { infrastructure }\end{array}$ & TQM \\
\cline { 2 - 4 } & Shared vision & Focus & Continuous improvement from japanese \\
\cline { 2 - 4 } & \multicolumn{3}{|c|}{ Process } \\
\hline
\end{tabular}

Source: Voss (1995) and Dhiravidamani et al. (2018).

According to Flights (1995), the key points of the paradigms can be expressed as follows:

Competing through manufacturing: This point can lead employees and managers to share a common vision, and create a debate among production, marketing and corporate strategists, but it must be supported by consistent decisions; 
Strategic choice: Probably the most powerful point to manufacturing strategy, it provides insight into the vast number of options a company has. It requires a manufacturing strategy development process; and

Best Practice: Companies are looking to best practices as the foundation of their manufacturing strategy. However, the big challenge is often to execute the project. Some more recent works also follow the same line of thought regarding the impact that manufacturing strategy has not only on an organization, but also on the environment in which it is inserted.

Perroni (2005) observes that manufacturing strategies have a direct influence on the industrial economy, considering that over time there has been a pattern of evolution between the paradigms of the Industrial Economy and those of the Manufacturing Strategy: production models are taken in it counts in the formatting of economic theories and at the same time the economic environment is observed and analyzed for the construction and fixation of production models.

For Singh and Mahmood (2014), the Manufacturing Strategy is an impulse that affects the company's capabilities and competitive advantage, which also has consequences on its performance in terms of export capacity.

\subsection{Manufacturing Audit}

The overall organization performance can be improved through an external quality audit (RAHMAN et al., 2019).

Shareholders, investors and international authorities may suggest that companies have quality audit programs (SATTAR et al., 2020).

For these authors, the process of identification, collection and structuring of information is a critical activity within the business strategy, thus, identifying the problem is an important step so that it can be solved.

This audit procedure guides the user through a logical process of identifying manufacturing objectives, measuring current manufacturing performance, determining the effects of current manufacturing practices, and identifying necessary changes.

The methodology is based on task sheets, which will be demonstrated throughout the article, which will ensure respect for each phase of the process. Therefore, it is a procedural approach to handling the manufacturing strategy (PLATTS; GREGORY, 1990). 
The process logic is explained in Figure 01.

Figure 01 - The logic of the manufacturing audit process

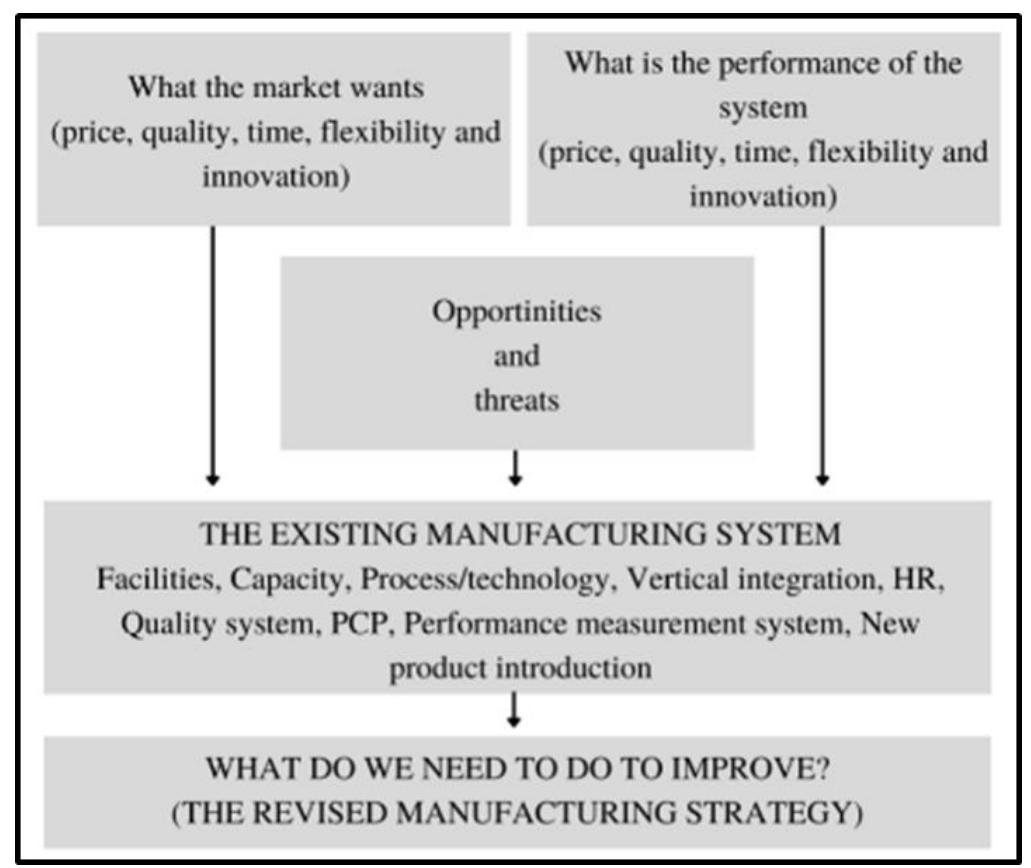

Source: Platts \& Gregory (1990).

In this way, the process is formed through the following task sheets:

- Task sheet number 01: Fulfillment of demands arising from the market in relation to the company's products, on the one hand, and the performance achieved in relation to these demands, on the other. This phase makes it possible to identify the difference between what the market requires and what the company offers.

- Task Sheet Number 02: Identifying the Most Important Product Families. Thus, the company can ensure that efforts are being concentrated in the most appropriate areas.

- Folha de tarefas número 03: Identificação sobre o que é mais importante para o mercado em relação aos produtos selecionados, para que os mesmos sejam competitivos.

- Task sheet number 04: Through this sheet, the company's performance is determined in relation to what was filled in on the previous sheet.

- Task Sheet Number 05: Identifying market threats and opportunities for the selected products. 
- Task Sheet Number 06: Completing Manufacturing Objectives and Areas Where Decisions Must Be Made. Practices in each area are identified to meet manufacturing objectives. The manufacturing operation can be broken down into nine areas: facilities, capacity, degree of vertical integration, processes, human resources, quality, control policies, suppliers and new products.

- Task sheet number 07: List of deficiencies in the manufacturing system in each area and what actions could be taken.

Other authors have also used the concepts of manufacturing auditing, but over time this theory has undergone modifications and updates (VEIGA; LIMA; COSTA, 2008; MAURI; MANICA, 2021). This study used an adaptation of the original concept of Platts and Gregory (1990) for small companies.

\section{METHODOLOGICAL PROCEDURES}

\subsection{Study object}

The literature review was carried out to situate the research topic in terms of its state of the art, defining how much literature has evolved on this topic, as well as its already formulated contributions. For the formation of the bibliographic portfolio, a semi-structured methodology was used, based on the principles of Pagani et al. (2015) e Lacerda et al. (2014). The searches were performed in the Scopus database, every one in the option "in topic", selecting as document type "only articles" with no date restrictions, in order to build the state of the art of the researched themes. For the research stage, two cycles of searches were carried out, with the keywords:

1) Audit and Manufacturing;

2) Strategy and Manufacturing, which were transcribed into English and the Boolean operator "and" was introduced for the research, which were presented as follows: "Audit" and "Manufacture" and "Strategy" and "Manufacture". After returning the search results, the titles and abstracts were read to exclude articles not aligned with the research objective, and finally, the bibliographic portfolio articles were read in full, thus defining the bibliographic portfolio Final.

The research is classified as applied research with a qualitative application approach, generating knowledge for practical application, aimed at solving specific problems (GERHARDT; SILVEIRA, 2009). 
By an exploratory study, the manufacturing audit approach is applied to the company in order to identify the strategy used, although it is not explicit. As for the objectives, the research is descriptive, as the application seeks to facilitate the understanding of the topic addressed by elucidating the characteristics of the process that involve the case analyzed.

For the analysis of technical procedures, it fits as a single case study, as the research investigates the phenomena in detail, enabling an understanding of the phenomenon studied through analysis and discussion of results, through interpretations and comparisons (PIRAN et al., 2016).

\subsection{Data Collection Procedures}

The company object of this study is located in a medium-sized municipality in the southwest of Paraná, the table is considered a microenterprise (SEBRAE, 2016). The company has been operating in the market for approximately 20 years, its administration is familiar. Its scope of operation in the market is predominantly regional (southwest region of the state), however, specifically with the sale of books, it extends to a national scope.

Data collection was carried out through observations, by a researcher with experience in the field of printed material and document analysis of the production reports of the product families selected for the study.

For the selection of the product family, monitoring was carried out for approximately one month in the company, which recorded all products manufactured and it was found that $80 \%$ of the organization's revenue for that month originated from pamphlets, blocks in general and newspapers (periodicals).

However, it was decided to select the newspapers for this study because it is the product with the highest revenue among the three and has weekly production frequency. In addition, it is a clientele with more than eight years of existence.

The application model for auditing the strategy of the studied environment, proposed by Platts and Gregory (1990), uses five evaluation aspects: Price, Quality, Time, Flexibility and Innovation. scale with five divisions. For the Price and Time aspects, the Very High scale indicates the lowest score value (1) and the Very Low scale indicates the highest score value (5), while for the Quality, Flexibility and Innovation aspects, the scales assume inverse values. 
Table 02 - Suggested Score for Audit Assessment

\begin{tabular}{l|l|l|l|l|c}
\multicolumn{1}{c|}{ Price } & \multicolumn{1}{|c|}{ Quality } & \multicolumn{1}{|c|}{ Time } & Flexibility & \multicolumn{1}{c|}{ Innovation } & Score \\
\hline Very high & Very low & Very high & Very low & Very low & 1 \\
\hline High & Baixa & High & Low & Low & 2 \\
\hline Moderate & Moderate & Moderate & Moderate & Moderate & 3 \\
\hline Low & High & Low & High & High & 4 \\
\hline Very low & Very high & Very low & Very high & Very high & 5
\end{tabular}

Source: Platts \& Gregory (1990).

\subsection{Data Analysis Procedures}

After the data collection, the model was applied and a matrix was assigned to the comparative relationships: Competitiveness Criteria X Performance achieved from pamphlets; Competitiveness criteria $\mathrm{X}$ Blocks performance achieved; Competitiveness criteria $\mathrm{X}$ Performance achieved from Periodicals. Once the assessment of the factors is completed, the opportunities and threats for the selected product family will be tabulated and thus it will be possible to define and structure the manufacturing strategy for the company under study.

Although the company is well structured in the municipality where it operates, it was identified that during its existence there was little or no investment in the professionalization of its employees, either through training in the application of methods aimed at increasing the quality of products or even of productivity. Thus, there is a training system in which an employee ends up learning their functions through contact with others, without a clear definition of a work procedure. Furthermore, there are no defined action strategies that can guide planning in this organization. In many industrial processes, non-value-added activities can comprise more than $90 \%$ of the total activities in a factory (DHIRAVIDAMANI et al., 2017).

To carry out the assessment, an adaptation to the model by Platts and Gregory (1990) was suggested. This adaptation consists of the adoption of a performance score, based on a 5 point scale, as presented in the methodological procedures in Table 02. 


\section{RESULTS}

In Table 03, the data obtained after the analysis of the competitiveness criteria in relation to the performance achieved with the pamphlets is presented.

Table 03 - Competitiveness criteria vs. performance achieved from flyers

\begin{tabular}{l|c|c|l|l} 
Product: & $\begin{array}{c}\text { Market } \\
\text { wants }\end{array}$ & Performance & Opportunities & Threats \\
\hline Price & 5 & 4 & Cost reduction & Aumento do Dólar \\
\hline Quality & 5 & 3 & Personnel training & Less defect tolerance \\
\hline Time (speed) & 4 & 5 & Training & Express industries \\
\hline Flexibility & 4 & 5 & Other printing systems & Virtual media \\
\hline Innovation & 4 & 3 & Tranining/ Partnerships & New equipment
\end{tabular}

Source: Survey data.

Table 03 shows the composition of the opportunities and threats found after assigning grades in the aspects "What does the market want?" and "Performance" in the comparison between the competitiveness criteria and the performance criteria achieved in the pamphlets process. Training is highlighted as an opportunity, which is presented in Quality, Speed and Innovation and as a threat, the increase in the dollar stands out, which is not under the domain of the manager, but directly affects the cost of production, as the the main inputs used to manufacture the pamphlets have their prices indexed based on dollar. Table 04 presents the comparative criteria between competitiveness and performance achieved by blocks.

Table 04 - Competitiveness Criteria X Performance of Blocks Achieved

\begin{tabular}{l|c|c|l|l} 
Product: & $\begin{array}{c}\text { Market } \\
\text { wants }\end{array}$ & Performance & Opportunities & Threats \\
\hline Price & 5 & 4 & Cost reduction & Increasing of dolar \\
\hline Quality & 5 & 3 & Personal training & Less defect tolerance \\
\hline Time (speed) & 4 & 5 & Training & Express industries \\
\hline Flexibility & 4 & 5 & Other printing systems & Virtual media \\
\hline Innovation & 4 & 3 & Tranining/ Partnerships & New equipment
\end{tabular}

Source: Survey data. 
By the data presented in Table 03, the opportunities and threats listed after the attribution of grades in the aspects "What does the market want?" and "Performance" in the comparison of competitiveness criteria with performance criteria achieved in blocks. Training can be highlighted as opportunities again, which is presented in Quality, Speed and Innovation, and also as threats, the increase in the dollar can be highlighted, which directly influences the production cost, as the paper and inks used for manufacturing the blocks have their prices indexed by dollar too, also as threats, competition was identified for express printers, which are not located in the same geographic region, but receive orders by digital means and deliver their products by carrier to any point from the country. Table 05 demonstrates the comparative criteria between competitiveness and performance achieved by journals.

Table 05 - Competitiveness Criteria X Performance of newspapers achieved

\begin{tabular}{l|c|c|l|l}
$\begin{array}{l}\text { Product: } \\
\text { Newspapers }\end{array}$ & $\begin{array}{c}\text { Market } \\
\text { wants }\end{array}$ & Performance & \multicolumn{1}{|c|}{ Opportunities } & \multicolumn{1}{c}{ Threats } \\
\hline Price & 5 & 4 & Cost reduction & Increasing of dolar \\
\hline Quality & 5 & 3 & Personal training & Less defect tolerance \\
\hline Time (speed) & 4 & 5 & Outsourcing / Training & Express industries \\
\hline Flexibility & 4 & 5 & Other printing systems & $\begin{array}{l}\text { Electronic sources of } \\
\text { information }\end{array}$ \\
\hline Innovation & 4 & 3 & Tranining/ Partnerships & New equipment
\end{tabular}

Source: Survey data.

Table 05 shows the last comparison of criteria, journals are the most sensitive products to the market that the printer has, but those that represent the highest revenue. Once again, training is highlighted as an opportunity, which is presented in Quality, Speed and Innovation, and also as a threat, the increase in the dollar stands out again, which directly influences the cost of production, in addition to the electronic sources of information that constantly has been taking space from printed newspapers. 


\section{DISCUSSION}

It was found that in terms of price, quality and innovation the company was below what the market demands. On the other hand, with regard to time and flexibility, it surpassed the market requirements. The objective of comparing the company's performance with the market demand is in line with the gathering of information to define the manufacturing strategy that can be adopted from this analysis. Short, medium and long-term actions can be developed in order to plan the company's strategy to the future.

The threats and opportunities identified in the three products are very similar, mainly considering their production process, which follows a pattern and uses the same materials. The main difference is verified with regard to periodicals, which suffer more from the threat that the virtual media impose on them, through which information is no longer updated daily and becomes updated in real time.

This characteristic ends up directly influencing the population's interest in the printed media and, consequently, the demand in the printing industries for this means of communication tends to decrease. Threats and opportunities for the newspaper process were listed in Table 06, with data originating from task sheet number 05.

Table 06 - Main Threats and Opportunities for the newspaper's family

\begin{tabular}{|c|c|}
\hline Threats & Opportunities \\
\hline High competition & Trend of increased interest of the population \\
\hline Zero consumer tolerance for defects & \\
\hline Global trend in preference for electronic information & Partnerships with competitors \\
\hline sources (real-time information) & $\begin{array}{l}\text { Insertion of new technologies that reduce } \\
\text { costs }\end{array}$ \\
\hline $\begin{array}{l}\text { Dollar increase and consequent increase in input costs such } \\
\text { as paper and ink }\end{array}$ & Personal training \\
\hline $\begin{array}{l}\text { Insertion of new technologies that make current equipment } \\
\text { obsolete }\end{array}$ & Partnerships with institutions \\
\hline
\end{tabular}

Source: Survey data.

It can be seen in Table 06 that there are many threats presented to the company's main product, but on the other hand, the opportunities presented stand out against the current scenario, and can overcome them. 
Table 07 shows the strategies currently adopted by the company: cost reduction of labor, reduction of waste, improvement of quality and reduction of lead time.

Table 07 - Manufacturing strategy for newspapers

\begin{tabular}{|c|c|c|c|}
\hline Objetive & Strategy & How to reach & Deadline \\
\hline \multirow{6}{*}{$\begin{array}{l}\text { Increase revenue from newspapers } \\
\text { (periodicals) }\end{array}$} & \multirow[b]{2}{*}{ Reduce labor cost } & $\begin{array}{l}\text { Professionalize the } \\
\text { performance of } \\
\text { tasks }\end{array}$ & Until August/2019 \\
\hline & & $\begin{array}{l}\text { Reduction of } \\
\text { excess employee } \\
\text { contingent }\end{array}$ & Until March/2019 \\
\hline & $\begin{array}{l}\text { Reduce costs with } \\
\text { wasted inputs }\end{array}$ & $\begin{array}{l}\text { Identification of } \\
\text { bottlenecks in the } \\
\text { production line }\end{array}$ & $\begin{array}{c}\text { Until } \\
\text { October/2019 }\end{array}$ \\
\hline & \multirow[t]{2}{*}{$\begin{array}{l}\text { Improve product } \\
\text { quality }\end{array}$} & $\begin{array}{l}\text { Professionalization } \\
\text { of tasks } \\
\text { performance }\end{array}$ & Until August/2019 \\
\hline & & $\begin{array}{l}\text { Identification of } \\
\text { new trends }\end{array}$ & $\begin{array}{c}\text { Until } \\
\text { November/2019 }\end{array}$ \\
\hline & $\begin{array}{ll}\text { Lead } & \text { Time } \\
\text { Reduction } & \end{array}$ & $\begin{array}{l}\text { Process } \\
\text { rationalization }\end{array}$ & Until August/2019 \\
\hline
\end{tabular}

Source: Survey data.

To reduce cost of the labor, the efforts seek to reach two relatively significant points: the professionalization of tasks and the reduction of excess employees. There is a relationship between both: low professionalization often tends to require a larger number of individuals to perform a certain task. Therefore, by concentrating efforts on preparing the employees' professional capacity, the demand for hiring will be lower.

The waste elimination strategy revolves around rationalization in the use of raw materials and greater concentration to avoid errors, which, in this field of activity, depending on the phase in which they occur, can cause the total loss of a production batch.

Cost reduction is something necessary for companies, as monitoring and controlling costs tend to become the driving force for improvements (GRACANIN et al., 2014). Although technologies involving the printing sector have evolved significantly in recent years, the assessment of the quality of its product is often done subjectively (VERIKAS et al., 2011; YANG et al., 2012). Anyway, identifying the bottlenecks present tends to make the process leaner.

Improving product quality is also directly related to the professionalization of tasks and employee training. Training and investment in personnel directly reflect on organizational 
performance or quality improvement itself (FENING et al., 2008; MARDANI et al., 2015; ASSARLIND; GREMYR, 2014; MENDES; LOURENÇO, 2014). Apparently, the process of professionalizing the workforce will be the biggest challenge for the company, as it is not an everyday activity.

The proposal to reduce lead time, through the rationalization of processes, will depend on the involvement of those involved. As the production, in this specific case, is processed through batches and not in-line, batches of different products are processed at the same time in different stages, with the risk of a product remaining for a long period of time waiting for the next step. It may not seem all that impactful, but this waiting time is costly. By rationalizing each stage of production of each product, machines and even idle employees will be avoided. In fact, reducing lead time is advantageous, as it allows for constant flows and reduces production time (KNOLLMANN et al., 2014).

The application of the Manufacturing Audit approach proposed by Platts and Gregory (1990) allowed the identification of manufacturing strategies more clearly for the studied company. The administration, despite basing the organization's management on individual experiences, usually without professional support from specialists in the area, showed only an intuitive knowledge of the company's weaknesses.

During the study, factors were identified that were below the levels of competitiveness required by the market (price and quality) for the newspaper/periodical, which were precisely those that the organization aims to improve. Lead Time, which has a specific strategy to be reduced, proved to be above market requirements. That is, the actions that are being developed tend to reach the main focus of the problems identified in the organization.

\section{CONCLUSION}

The proposal for applying this methodology has demonstraded to be objective and flexible for adaptation. With the information obtained and analyzed, it was possible to identify the manufacturing strategies used by the companies, their strengths and weaknesses and the actions that need to be developed. The characteristics of the adapted methodology enable debate, interaction of ideas, feedback and a constant learning process.

It appears, therefore, that the application of this adaptation of the original methodology had a low cost, encouraged strategic thinking for this size of company, which also allowed its 
directors a broader view of their business through the identification of threats and opportunities. The manufacturing strategy can be fundamental, as it allows direct actions on the production line, in order to make it leaner and more competitive. Small and medium-sized companies can benefit from this approach model, which, through practical and forceful actions, interferes with basic and fundamental strategic issues for an organization.

The importance that small and medium-sized companies have for Brazil reinforces the contribution generated by work, which can also be applied in other scenarios and countries, as long as the particularities and intrinsic characteristics of each application are respected. It was also found that the most advanced manufacturing audit studies, aimed at small and mediumsized companies, especially the printing industries, are scarce, and this highlights the importance of leveraging results for these companies, which traditionally do not realize the importance of adapting already consolidated methodologies in large companies for their context.

The development of the methodology with this approach provides a possible starting point for further studies in the explored area, a sector that has been undergoing many transformations due to the technological evolution of the means of information communication. The challenge of professionalizing processes in small and medium-sized companies is evident and manufacturing audits applied in these companies can help in decisions, identifying bottlenecks for process improvement.

\section{References}

ABIGRAF, Brazilian Association of the Graphic Industry. Sectoral study of the graphic industry in Brazil. Available in:

$<$ http://www.setorgrafico.org.br/enquadramento_sindical/Estudo\%20Setorial\%20da\%20Ind\% C3\%BAstria\%20Gr\%C3\%A1fica\%20no\%20Brasil-Sebrae.pdf>. Access in: January 10, 2021.

ABIGRAF, Brazilian Association of the Graphic Industry. Abigraf-SC claims reduction of ICMS for the graphic sector in the state. Available in: < http://www.abigraf.org.br/namidia/noticias/abigraf-sc-pleiteia-reducao-do-icms-para-o-setor-grafico-no-estado>. Access in: April 13, 2021.

ABIGRAF, Brazilian Association of the Graphic Industry. Economics data http://www.abigraf.org.br/na-midia/abigraf-em-acao/dados-economicos. 2019

ABIGRAF, Brazilian Association of the Graphic Industry. Printing indústria in Brazil http://www.abigraf.org.br/. 2015 
ARAFA, A.; ELMARAGHY, W. H. Manufacturing strategy and enterprise dynamic capability. CIRP Annals - Manufacturing Technology, v. 60 , p. 507-510, 2011.

ASSARLIND, M.; GREMYR, I. Critical factors for quality management initiatives in small and medium-sized enterprises. Total Quality Management \& Business Excellence, v. 25, n. 3, p. 397-411, 2014.

AWWAD, A.; AL KHATTAB, A.; ANCHOR, J. R. Competitive Priorities and Competitive Advantage in Jordanian Manufacturing. Journal of Service Science and Management, v. 6, p. 69-79, 2013.

BOUCHER, X.; BONJOUR, E.; GRABOT, B. Formalisation and use of competencies for industrial performance optimisation: A survey. Computers in Industry, v. 58, n. 2, p. 98117, 2007.

DESHMUKH, S. V.; CHAVAN, A. Sis Sigma and SMEs: a critical review of literature. International Journal of Lean isx Sigma, v. 3, p. 157-167, 2012.

DHIRAVIDAMANI, P.; RAMKUMAR, A. S.; PONNAMBALAM, S. G.; SUBRAMANIAN, N. Implementation of lean manufacturing and lean audit system in an auto parts manufacturing industry - an industrial case study. International Journal of Computer Integrated Manufacturing, v. 31, p. 1-29, 2018.

DHIRAVIDAMANI, P.; RAMKUMAR, A. S.; PONNAMBALAM, S. G.; SUBRAMANIAN. Implementation of lean manufacturing and lean audit system in an auto parts manufacturing industry - an industrial case study. International Journal of Computer Integrated Manufacturing, 2017.

FENING, F. A.; PESAKOVIC, G.; AMARIA, P. Relationship between quality management practices and the performance of small and mediumsize enterprises (SMEs) in Ghana. International Journal of Quality \& Reliability Management, v. 25, n. 7, p. 694-708, 2008.

FIEP, Federation of Industries of the State of Paraná. Productive chains. Disponível em: < http://www.fiepr.org.br/fomentoedesenvolvimento/cadeiasprodutivas/>. Access in: April 13, 2021.

FILHO, J. R.; NUNES, G. S. The Brazilian Private Micro, Small and Medium Enterprise Strategist. Revista Brasileira de Gestão de Negócios, v. 12, n. 36, p. 271-288, 2010.

GERHARDT, T. E.; SILVEIRA, D. T. Research methods. Porto Alegre: UFRGS, 2009.

GOBBO, S. C. O.; RODRIGES, J. S.; JUNIOR, J. A. G.; FUSCO, J. P. A. An analysis of the manufacturing strategies adopted by six automakers in the world auto industry. Revista GEPROS. Gestão da Produção Operações e Sistemas, v. 5, n. 3, p. 11-28, 2010. 
GOLEC, A. A relationship framework and application in between strategy and operational plans for manufacturing industry. Computers \& Industrial Engineering, v. 86, p. 83-94, 2015.

GRACANIN, D.; BUCHMEISTER, B.; LALIC, B. Using Cost-Time Profile for Value Stream Optimization. Procedia Engineering, v. 69, p. 1225-1231, 2014.

GRANILLO-MACÍAS， R.; SIMÓN-MARMOLEJO， I.; GONZÁLEZ-HERNÁNDEZ， I.; ZUNO-SILVA, J. Traceability in industry 4.0: a case study in the metal mechanical sector, Acta logística, v.7, n. 2, p. 95-101, 2020.

HAYES, R.; PISANO, G. Beyond world-class: the new manufacturing strategy. Harvard Business Review, p. 77-86. 1994.

HAYES, R.; WHEELWRIGHT, S. Competing through manufacturing. Harvard Business Review, p. 99-109, 1985.

HEINZMANN, L. M.; LAVARDA, R. A. B.; MACHADO, D. D. P. N.; HEIN, N. Manufacture strategy stages and strategy-as-practice phases. Revista de Ciências da Administração, v. 15, n. 36, p. 245-258, 2013.

JIA, G. Z.; BAI, M. An approach for manufacturing strategy development based on fuzzyQFD. Computers \& Industrial Engineering, v. 60, p. 445-454, 2011.

KAI, D. A.; CONCEIÇÃO, R. I.; LIMA, E. P.; COSTA, S. E. G. Conceptual model for the introduction of sustainability practices in the printing industry operations. Revista GEPROSGestão da Produção Operações e Sistemas, v. 9, n. 4, p. 1-18, 2014.

KNOLLMANN, M.; WINDT, K.,; DUFFIE, N. Evaluation Of Capacity Control And Planned Lead Time Control In A Control-Theoretic Model. Procedia CIRP, v. 17, p. 392-397, 2014.

LACERDA, R. T. D. O.; ENSSLIN, L.; ENSSLIN, S. R. Research opportunities in strategic management field: a performance measurement approach. Int. J. Bus. Perform. Manag. v. 15, p.158, 2014.

LIZOT, M.; JÚNIOR, P.P.A.; TROJAN, F.; THESARI, S.S.; GOFFI, A.S. Analysis of evaluation methods of sustainable supply chain management in production engineering journals with high impact. Sustainability (Switzerland), v. 12, n. 1, 270 p. 1-20, 2020.

MARDANI, A.; JUSON, A.; BAGHERI, M. M.; KAZEMILARI, M. A combined hybrid fuzzy multiple criteria decision-making aproach to evaluating of QM critical success factores in SME's Hotels Firms. Procedia- Social and Behavorial Sciences, v. 172, p. 786-793, 2015.

MAURI, J. C.; MANICA, C. R. Application of Industry 4.0 Enabling Technologies to Assist Industrial Traceability in Electrical Cable Manufacturing. Scientia cum Industria, v. 9, v. 1, p.1, 2021. 
MENDES, L.; LOURENÇO, L. Factors that hinder quality improvement programs' implementation in SME: definition of a taxonomy. Journal of Small Business and Enterprise Development, v. 21, n. 4, p. 690-715, 2014.

MINTZBERG, H. The Strategy Concept I: Five Ps for Strategy. California Management Review, p. 30, 1987.

NAIR, A.; SINGH, J. P.; BHATTACHARYA, A.; PAL, S. Withstanding the economic recession: Examining the efficacy of manufacturing strategy alignment and process integration. International Journal of Production Economics, v. 231, n. 107810, 2021.

NURCAHYO, R.; WIBOWO, A. D. Manufacturing Capability, Manufacturing Strategy and Performance of Indonesia Automotive Component Manufacturer. Procedia CIRP, v. 26, p. 653-657, 2015.

PAGANI, R. N.; KOVALESKI, J. L.; RESENDE, L. M. Methodi Ordinatio: a proposed methodology to select and rank relevant scientific papers encompassing the impact factor, number of citation, and year of publication. Scientometrics. v.105, p. 2109-2135, 2015.

PATAH, L. A., \& CARVALHO, M. M. Alignment between project organizational structure and manufacturing strategy: a comparative analysis of multiple cases. Gestão e Produção, v.16, p. 301-312, 2009.

PERRONI, M. G. (2005). nterrelationships of the Evolution of Industrial Economy Paradigms with Manufacturing Strategy Paradigms. Dissertation - Pontifícia Universidade Católica do Paraná. Programa de Pós-Graduação em Engenharia de Produção e Sistemas, $131 \mathrm{p}$.

PIRAN, F. A.; NUNES, A. A.; SOUZA, M. A.; NUNES, F. D. Strategic positioning, manufacturing strategies and cost management: a case study in a company in the metalworking segment. Revista Contemporânea de Contabilidade, p. 81-98, 2016.

PLATTS, K. W.; MILLS, J. F.; NEELY, A. D.; GREGORY, M. J.; RICHARDS, A. H. Evaluating manufacturing strategy formulation processes. International Journal Production Economics, 46, p. 233-240. 1996.

PLATTS, K.; GREGORY, M. Manufacturing audit in the process of strategy formulation. International Journal of Operations \& Production Management, v. 10, p. 5-26. 1990.

PORTER, M. What's strategy. Harvard Business Review, p. 61-78, 1996.

RAHMAN, M.; MEAH, M. R.; CHAUDHORY, N. U. The Impact of Audit Characteristics on Firm Performance: An Empirical Study from an Emerging Economy. Journal of Asian Finance, Economics and Business, v. 6, n. 1, p. 59-69, 2019. 
SATTAR U, JAVEED SA, LATIEF R. How Audit Quality Affects the Firm Performance with the Moderating Role of the Product Market Competition: Empirical Evidence from Pakistani Manufacturing Firms. Sustainability, v. 12, n. 10:4153, 2020.

SATTAR, U.; JAVEED, S. A.; LATIEF, R. How Audit Quality Affects the Firm Performance with the Moderating Role of the Product Market Competition: Empirical Evidence from Pakistani Manufacturing Firms. Sustainability, v.12, p. 4153, 2020.

SEBRAE, Brazilian Micro and Small Business Support Service. Micro and small businesses generate $27 \%$ of Brazil's GDP. Available in: <http://www.sebrae.com.br/sites/PortalSebrae/ufs/mt/noticias/micro-e-pequenas-empresasgeram-27-do-pib-do-brasil,ad0fc70646467410VgnVCM2000003c74010aRCRD>. Access in: December 13, 2018.

SEBRAE. Brazilian Micro and Small Business Support Service. Available in: http://www.sebrae-sc.com.br. Access in: October 08, 2018.

SEBRAE/ABIGRAF. Sectorial Study of the Graphic Industry in Brazil http://www.setorgrafico.org.br/enquadramento_sindical/Estudo\%20Setorial\%20da\%20Ind\%C 3\%BAstria\%20Gr\%C3\%A1fica\%20no\%20Brasil-Sebrae.pdf. 2009

SHAH, P. P.; SHRIVASTAVA, R. L. Identification of performance measures of Lean Six Sigma in small and Medium-sized enterprises: a pilot study. International Journal of Six Sigma and Competitive Advantage. v. 08, n. 01, p. 01-21, 2013.

SINGH, H.; MAHMOOD, R. Aligning Manufacturing Strategy to Export Performance of Manufacturing Small and Medium Enterprises in Malaysia. Procedia - Social and Behavioral Sciences, v. 30, p. 85-95, 2014.

SKINNER, W. The focused factory. Harvard Business Review, p. 113-121, 1974.

THUN, J. H. Empirical analysis of manufacturing strategy implementation. Int. J. Production Economics, v. 113, p. 370-382, 2008.

VEIGA, G. L.; LIMA, E. P.; COSTA, S. E. G. A discussion on the strategic role of the Lean Production Model. Sistemas \& Gestão, v.3, n. 2, p.92-113, 2008.

VERIKAS, A.; LUNDSTRÖM, J.; BACAUSKIENE, M.; GELZINIS, A. Advances in computational intelligence-based print quality assessment and control in offset colour printing. Expert Systems with Applications, v. 38, p. 13441-13447, 2011.

VOSS, C. A. Alternative paradigms for manufacturing strategy. International Journal of Operations \& Production Management, v. 15, n. 4, p. 5-16, 1995.

WEBER, W.; POLO, E. F. Inaccuracy in Strategic Management: an approach based on Complex Thinking. Revista Brasileira de Gestão de Negócios, v. 9, n. 24, p. 75-90, 2007. 
YANG, Y.; MING, J.; YU, N. Color image quality Assesment based on CIEDE2000. Advances In Multimedia, p. 6, 2012. 